\title{
Improvement of the Nutritional Value of Cereal Fermented Milk: 1- Soft Kishk Like Nassar KS ${ }^{1 *}$, Shamsia SM$^{1}$ and Attia IA $^{2}$
}

${ }^{1}$ Department of Food, Dairy Science and Technology, University of Damanhour, Egypt

${ }^{2}$ Department of Dairy Science and Technology, Alexandria University, Egypt

\begin{abstract}
Soft Kishk like products were produced from whole wheat, barley and freek burghul with reconstituted skim milk (15\% T. S) and addition of different Starter cultures. Physico-chemical, bacteriological and organoleptic properties of soft kishk like samples have been evaluated during 14 days of storage at $5 \pm 1^{\circ} \mathrm{C}$. The main effect on Soft Kishk like products characteristics was due to the used cereal type more than the started culture. Containing wheat burghul showed the highest $\mathrm{pH}$ values, Crude protein content were almost similar between all treatments as a result of the similarity of protein content in the selected seeds. Freek burghul treatment-showed higher total solids and carbohydrates whereas, lower content of ash, crude fiber, fat and crude protein contents compared to the other treatments. The c.f.u on MRS medium (mainly Bifidobacteria) sensitive than other starter microorganisms (mainly lactic acid bacteria) for storage. Cereal fermented dairy products containing Freek; gained the highest scores in the organoleptic properties followed by wheat. While the addition of whole barley burghul had the lowest total score at the end of storage. Therefore, a functional and nutritional Kishk like products have been successfully produced using different cereals and probiotic starter cultures.
\end{abstract}

Keywords: Fermentation; Cereal; Probiotic bacteria; Kishk; Milk

\section{Introduction}

There is a currently growing interest in certain strains of lactic acid bacteria that have been suggested or shown to provide specific health benefits when consumed as food. The history of those observations had started in the early 1900's, when Élie Metchnikoff noted the longevity of people living in the Balkans, and attributed this to their high consumption of fermented milk products [1].

Following those early observations, scientists reported that yogurt and other fermented milk products contain lactic acid bacteria that are capable of establishing and colonizing the gut, this group of bacteria referred to as probiotic bacteria [2]. Probiotics are live microbial food supplements, which beneficially affect the host animal by improving its intestinal microbial balance [3]. Recently, some foods, as called functional foods that have positive health promoting effects are already on the global market, and especially in the markets of Japan, Europe, and United states. Functional foods are defined broadly as foods that provide more than simple nutrition; they supply additional physiological benefits to the consumer. Yoghurt and other fermented milks containing probiotics may be considered the first functional foods [2-4].

Cereals are providing dietary fibers, proteins, energy, minerals and vitamins required for human health. The possible applications of cereal constituents in functional food formulations could be summarized: (a) as dietary fiber promoting several beneficial health or physiological effects; (b) as prebiotics due to their content of specific non digestible carbohydrates; and (c) as encapsulation materials for probiotics in order to enhance their stability [5]. However, the nutritional quality of cereals and the sensorial properties of their products are sometimes poor or inferior in comparison with milk and milk products. Milk proteins have high nutritional value compared to other proteins because of their relatively high content of essential amino acids and good digestibility [6].

During fermentation of dairy products like cheese and yoghurt release bioactive peptides upon enzymatic hydrolysis of milk proteins [7]. Fermentation may be the most simple and economical way of improving nutritional value, sensory properties and functional qualities of the dairy products [8]. Lactic acid fermentation of different cereals has been found effectively to reduce the amount of Phytic acid, tannins and improve protein availability [9]. Increased amounts of riboflavin, thiamine, niacin and lysine due to the action of LAB in fermented blends of cereals where also reported [10]. The traditional foods manufactured from grains usually lack flavor and aroma. Fermentation improves the sensorial value, which is very much dependent on the amounts of lactic acid, acetic acid and several aromatic volatiles such as higher alcohols, aldehydes, ethyl acetate and di-acetyl, produced via the homo-fermentative or hetero-fermentative metabolic pathways [11]. This work aimed to produce probiotic cereals fermented milk supplemented. The cereals were as wheat, barley and Fereek (green wheat), in order to introduce a diet with nutritionally balanced that needed for sensitive or elderly persons.

\section{Materials and Methods}

\section{Cereals}

Three different cereals; namely: Dry Wheat (Triticum spp.), Barley (Hordeum spp.) and Green Wheat or Fereek (Triticum spp.), were purchased from local market (Alexandria, Egypt). Dried skim milk was obtained from Alexandria market.

\section{Starters}

Three commercial freeze-dried DVS were used. They were a Yoghurt starter (YC-X11) (Streptococcus thermophilus + Lactobacillus delbruckii subsp. bulgaricus); Bio-yoghurt starter (ABT-2) (CHR HANSEN) + Yoghurt starter (1:2) and Lactobacillus plantarum + Yoghurt starter (1:2) with potential probiotic properties (From Chr.

*Corresponding author: Nassar KS, Department of Food, Dairy Science and Technology, University of Damanhour, Egypt, Tel: +20-453368069; E-mail: Khalid.nassar@agr.dmu.edu.eg

Received August 19, 2016; Accepted September 07, 2016; Published September 12, 2016

Citation: Nassar KS, Shamsia SM, Attia IA (2016) Improvement of the Nutritional Value of Cereal Fermented Milk: 1- Soft Kishk Like. J Food Process Technol 7: 619. doi: 10.4172/2157-7110.1000619

Copyright: $\odot 2016$ Nassar KS, et al. This is an open-access article distributed under the terms of the Creative Commons Attribution License, which permits unrestricted use, distribution, and reproduction in any medium, provided the original author and source are credited. 
Hansen laboratory, Denmark). Freeze -dried bacterial starters were propagated separately as mother cultures in autoclaved $\left(121^{\circ} \mathrm{C} / 20 \mathrm{~min}\right)$ skim milk. The cultures were incubated at $37^{\circ} \mathrm{C}$ for Bio-yoghurt starter, $32^{\circ} \mathrm{C}$ for Lactobacillus plantarum and $40^{\circ} \mathrm{C}$ for yoghurt starter, until curding of milk. Cultures were freshly prepared before using.

\section{Preparation of whole wheat burghul, whole barley burghul and fereek burghul}

The polished (wheat, Barley and Fereek) $(0.5 \mathrm{~kg})$ was cleaned manually by removing foreign grains and other impurities. Then, it was placed in a stainless steel sieve and washed under a strong stream of tap water with continuous stirring for two minutes followed by rinsing with distilled water. Cleaned and washed polished wheat was cooked in a Stainless-steel pot containing $(1.5 \mathrm{~L})$ of water. Cooking time was between 25-30 minutes from the beginning of boiling until the completion of cooking and absorption of the water. The cooked grains were left to cool then broken up a blender.

\section{Preparation of reconstituted skim milk (15 w/w)}

$150 \mathrm{gm}$ of the dried skim milk were dispersing by stirring in $600 \mathrm{gm}$ distilled water at $40^{\circ} \mathrm{C}$, then complete to $1000 \mathrm{gm}$ with distilled water vigorously stirring until completely dissolving

\section{Preparation of cereal fermented dairy products or soft kishk like}

Each type of Burghul was mixed with reconstituted skim milk in a ratio of $1: 4(\mathrm{w} / \mathrm{w})$ in addition to, suitable amount of vanillin. The final total solids of mixture were $26 \%$. Mixture was heated to $95^{\circ} \mathrm{C}$ for 10 seconds, and then rapidly cooled to $45^{\circ} \mathrm{C}$, addition $3 \%$ of each Starter. The ingredients (reconstituted skim Milk + Cereal + starter culture) were mixed thoroughly before adding. The resultant paste was filled in polystyrene cups and covered then incubated at $\left(43^{\circ} \mathrm{C}\right.$ for $\mathrm{W} 1, \mathrm{~B} 1$ and $\mathrm{F} 1)$ and $\left(37^{\circ} \mathrm{C}\right.$ for $\mathrm{W} 2, \mathrm{~W} 3, \mathrm{~B} 2, \mathrm{~B} 3, \mathrm{~F} 2$ and F3) to 6 hours. After that, the fermented paste was stored at $5 \pm 1^{\circ} \mathrm{C}$ (refrigerator temperature) (Figure 1).

\section{Chemical Analysis}

\section{Dairy base analysis}

Dried skim milk is analyzed for total solids (TS), Protein, Ash, titratable acidity, $\mathrm{pH}$ and Total carbohydrate content according to the Association of Official Analytical Chemists [12] (Table 1).

\section{Cereals analysis}

Cereals were analyzed for total solids (TS), Fat, Protein, Ash, Total carbohydrate and crude fiber content according to AACC [13] (Table 2).

\section{Kishk like analysis}

The samples were analyzed in triplicates for $\mathrm{pH}$, titratable acidity as lactic acid, and Total solids in the fresh products and after 7 and 14 days of storage at $5 \pm 1{ }^{\circ} \mathrm{C}$, whereas, total protein, carbohydrate, ash, crude fibers and the fat content were determined only in the fresh products.

Total solids content, total protein, fat, ash and crude fibers were determined as described by AOAC [12]. $\mathrm{pH}$ values were measured using a pH-meter model HANNA HI9321 microprocessor with a standard, combination glass electrode. Titratable acidity was estimated as percentage of lactic acid according to [14]. The carbohydrate content was calculated in the product according to the following equation:

Carbohydrate $\%=100-($ Protein $\%+$ Ash $\%+$ Fat $\%+$ Fiber $\%)$

Reconstituted dried skim milk (15\% T.S)

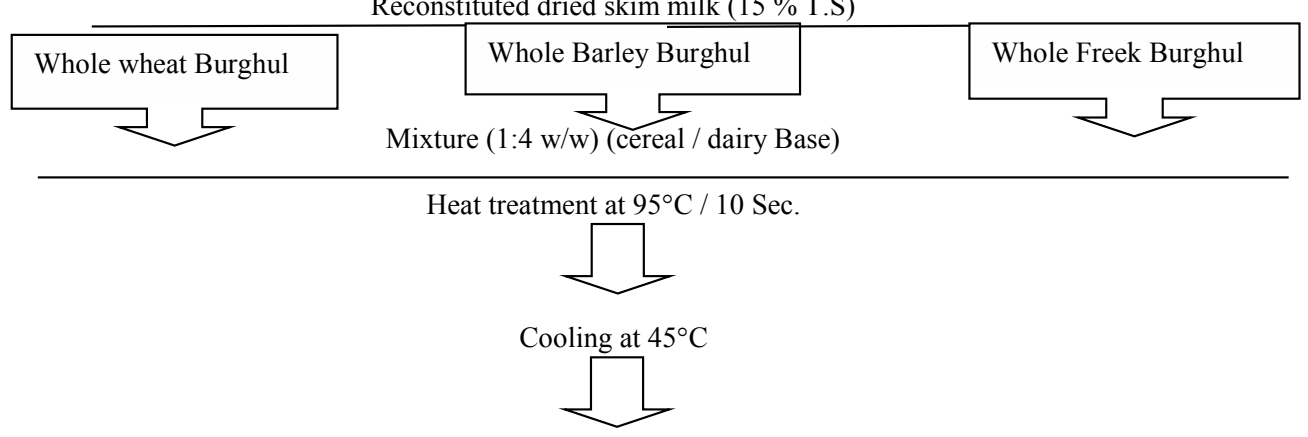

Addition of different Starter cultures (3\%)

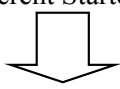

Filling in plastic cups (100 gm.)

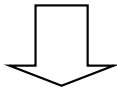

Incubation at suitable temperature until desired $\mathrm{pH}$

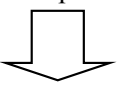

Cooling to room temperature

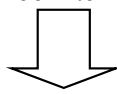

Storage at $5 \pm 1^{\circ} \mathrm{C}$ for 14 days

Figure 1: The manufacturing of Kishk like. 
Citation: Nassar KS, Shamsia SM, Attia IA (2016) Improvement of the Nutritional Value of Cereal Fermented Milk: 1- Soft Kishk Like. J Food Process Technol 7: 619. doi: 10.4172/2157-7110.1000619

Page 3 of 7

\begin{tabular}{|c|c|c|c|c|c|}
\hline \multirow{2}{*}{ Treatments } & \multicolumn{3}{|c|}{ Cereals } & \multirow{2}{*}{\begin{tabular}{|c|} 
Dairy base \\
Re-constituted Skim milk (15\%)
\end{tabular}} & \multirow{2}{*}{ Vanillin } \\
\hline & Whole Wheat Burghul (W) & Whole Barley Burghul (B) & Freek Burghul (F) & & \\
\hline \multirow{3}{*}{1} & $\sqrt{ }$ & & - & $\sqrt{ }$ & $\sqrt{ }$ \\
\hline & - & $\sqrt{ }$ & - & $\sqrt{ }$ & $\sqrt{ }$ \\
\hline & - & - & $\sqrt{ }$ & $\sqrt{ }$ & $\sqrt{ }$ \\
\hline \multirow{3}{*}{2} & $\sqrt{ }$ & & - & $\sqrt{ }$ & $\sqrt{ }$ \\
\hline & - & $\sqrt{ }$ & - & $\sqrt{ }$ & $\sqrt{ }$ \\
\hline & - & - & $\sqrt{ }$ & $\sqrt{ }$ & $\sqrt{ }$ \\
\hline \multirow{3}{*}{3} & $\sqrt{ }$ & - & - & $\sqrt{ }$ & $\sqrt{ }$ \\
\hline & - & $\sqrt{ }$ & - & $\sqrt{ }$ & $\sqrt{ }$ \\
\hline & - & - & $\sqrt{ }$ & $\sqrt{ }$ & $\sqrt{ }$ \\
\hline \multicolumn{6}{|c|}{$\begin{array}{l}\text { 1: ( } 3 \% \text { Yoghurt starter }) \\
2:(2 \% \text { Yoghurt starter }+1 \% \text { Bio-yoghurt starter }) \\
\text { 3: ( } 2 \% \text { Yoghurt starter }+1 \% \text { Lactobacillus plantarum })\end{array}$} \\
\hline
\end{tabular}

Table 1: Experimental treatments.

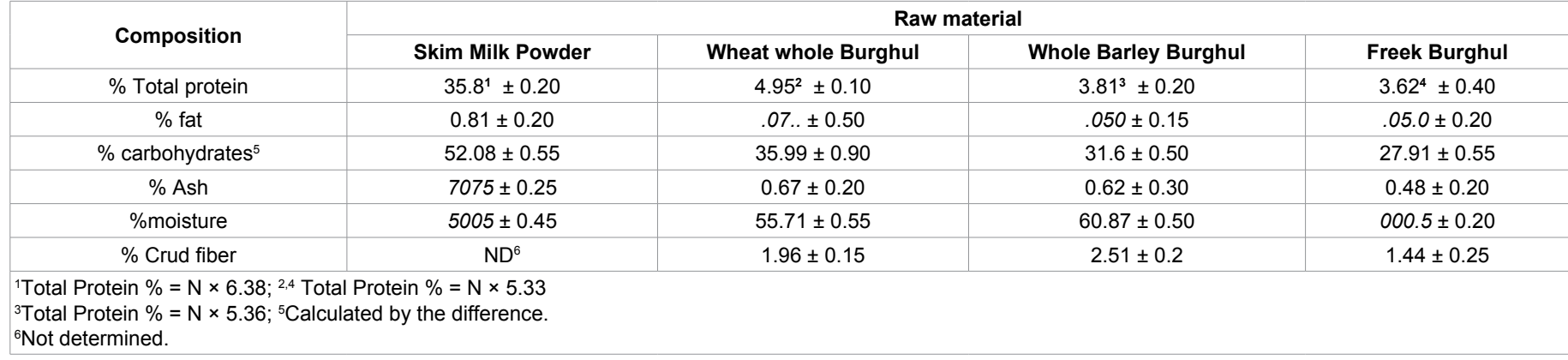

Table 2: Characteristics of the raw materials used in manufacture of Kishk like.

\section{Sensory evaluation}

Organoleptic evaluation was carried out according to the scheme of Clark et al. [15]. The samples were subjected to organoleptic analysis by well-trained members of the Dairy Science and Technology Department (Fac. Agric. Alexandria Univ., Egypt). The sensory attributes evaluated were: The Flavor (1-10 points), Body and Texture (1-5 points) and appearance and Colour (1-5 points).

\section{Microbiological analysis}

Preparation of the samples: Eleven grams of each sample were weighted and transferred thoroughly under condition to sterilized flasks, contained $99 \mathrm{ml} 2 \%$ sodium citrate solution. The necessary serial dilutions using sterilized distilled water were carried out. The samples were mixed by an electric blender for about $2 \mathrm{~min}$. The following microbial were enumerated.

Lactic acid bacterial count (LAB): Using de Man Rogosa Sharpe Agar medium (MRS) as described by APHA [16]. The plates were incubated at $37^{\circ} \mathrm{C}$ for 48 hours.

Coliform count: Coliform bacteria were enumerated using Violet Red Bile Agar (VRBA) medium according to Difco [17]. The plates were incubated at $37^{\circ} \mathrm{C}$ for 24 hours.

Yeasts and moulds count: Sabouraud dextrose agar medium (Oxoid) was used for enumerating yeasts and moulds according to APHA [16]. The plates were incubated at room temperature $\left(20^{\circ} \mathrm{C}-25^{\circ} \mathrm{C}\right)$ for $5-7$ days.

Lactobacillus acidophilus count: Lactobacillus acidophilus was counted on MRS ager (Oxoid) supplemented with L-cystein according to Lapierra et al. [18].

Proteolytic bacteria: Proteolytic bacteria count was enumerated on nutrient agar (NA) according to APHA [16]. The plates were incubated at $32^{\circ} \mathrm{C}$ for $38-48 \mathrm{hrs}$.

Spore forming bacterial count: Representative sample was heated at $80^{\circ} \mathrm{C}$ for $20 \mathrm{~min}$ in water bath and then cooled at the room temperature, the same technique as previously mentioned was followed for enumeration the spore formers but using manitol salt agar medium (MSA) Incubation was done at $32^{\circ} \mathrm{C}$ for $24 \mathrm{hrs}$ [16].

\section{Statistical analysis}

Statistical analysis was performed by applying three ways ANOVA and multiple comparisons of means of each treatment (cereals, starter cultures and storage time) using the Least Significant Difference (LSD) test at the confidence level of $95 \%$. Analysis of data was carried out with SAS [19].

\section{Results and Discussion}

\section{Chemical composition}

Chemical properties of cereal fermented dairy products are presented in Tables 3 and 4. The results (Table 3) revealed that the effect of cereal type on the chemical composition of the resultant cereal fermented dairy products was more pronounced $(P \leq 0.05)$ than that of type of starter culture used. There are significant differences $(\mathrm{P} \leq$ $0.05)$ in $\mathrm{pH}$ values and acidity percentages between different cereals fermented dairy products, depending on the type of cereal or starter culture. Data in Table 3 show that the $\mathrm{pH}$ values of all samples were decreased gradually till 14 days of the storage, whereas the titratable acidity values were increased at the same period of cold storage. These expected results due to the starter activity similar results were obtained by Hussein [20]. The cereal fermented dairy products containing wheat (W1, W3 and W2, Respectively) were characterized by higher 
$\mathrm{pH}$ as compared with their containing of Barely (B1, B3 and B2) and Freek (F1, F3 and F2, Respectively). However, samples of cereal

\begin{tabular}{|c|c|c|c|}
\hline Samples & $\begin{array}{l}\text { Storage Period } \\
\text { (days) }\end{array}$ & $\begin{array}{c}\text { Acidity as lactic } \\
\text { acid }\end{array}$ & pH \\
\hline S.W.1 & $\begin{array}{c}1 \\
7 \\
14\end{array}$ & $\begin{array}{c}0.630^{\mathrm{NM}} \\
0.843^{\mathrm{FG}} \\
0.943^{\mathrm{BDC}}\end{array}$ & $\begin{array}{l}4.87^{\mathrm{A}} \\
4.64^{\mathrm{FE}} \\
4.52^{\mathrm{HIJ}}\end{array}$ \\
\hline S.W.2 & $\begin{array}{c}1 \\
7 \\
14\end{array}$ & $\begin{array}{c}0.676^{\mathrm{LM}} \\
0.883^{\mathrm{EF}} \\
0.966^{\mathrm{ABC}}\end{array}$ & $\begin{array}{c}4.80^{\mathrm{AB}} \\
4.46^{\mathrm{LKMJ}} \\
4.38^{\mathrm{ON}}\end{array}$ \\
\hline S.W. 3 & $\begin{array}{c}1 \\
7 \\
14\end{array}$ & $\begin{array}{l}0.656^{\mathrm{LM}} \\
0.863^{\mathrm{EFG}} \\
0.950^{\mathrm{ABC}}\end{array}$ & $\begin{array}{c}4.83^{\mathrm{AB}} \\
4.53^{\mathrm{HI}} \\
4.400^{\mathrm{MN}}\end{array}$ \\
\hline S.B.1 & $\begin{array}{c}1 \\
7 \\
14\end{array}$ & $\begin{array}{c}0.690^{\mathrm{LK}} \\
0.850^{\mathrm{EFG}} \\
0.936^{\mathrm{DC}}\end{array}$ & $\begin{array}{l}4.80^{\mathrm{BC}} \\
4.55^{\mathrm{HG}} \\
4.48^{\mathrm{LKIJ}}\end{array}$ \\
\hline S.B.2 & $\begin{array}{c}1 \\
7 \\
14\end{array}$ & $\begin{array}{l}0.760^{\mathrm{IJ}} \\
0.896^{\mathrm{ED}} \\
0.986^{\mathrm{AB}}\end{array}$ & $\begin{array}{c}4.73^{\mathrm{CD}} \\
4.51^{\mathrm{HKIJ}} \\
4.44^{\mathrm{LKMN}}\end{array}$ \\
\hline S.B. 3 & $\begin{array}{c}1 \\
7 \\
14\end{array}$ & $\begin{array}{c}0.750^{\mathrm{IJ}} \\
0.886^{\mathrm{EF}} \\
0.993^{\mathrm{A}}\end{array}$ & $\begin{array}{c}4.76^{\mathrm{BCD}} \\
4.53^{\mathrm{HI}} \\
4.42^{\mathrm{LMN}}\end{array}$ \\
\hline S.F.1 & $\begin{array}{c}1 \\
7 \\
14\end{array}$ & $\begin{array}{l}0.550^{\circ} \\
0.673^{\mathrm{LM}} \\
0.786^{\mathrm{IH}}\end{array}$ & $\begin{array}{l}4.72^{\mathrm{D}} \\
4.65^{\mathrm{FE}} \\
4.52^{\mathrm{HIJ}}\end{array}$ \\
\hline S.F.2 & $\begin{array}{c}1 \\
7 \\
14\end{array}$ & $\begin{array}{c}0.603^{\mathrm{N}} \\
0.776^{\mathrm{IHJ}} \\
0.850^{\mathrm{EFG}}\end{array}$ & $\begin{array}{l}4.70^{\mathrm{ED}} \\
4.52^{\mathrm{HIJ}} \\
4.35^{\circ}\end{array}$ \\
\hline S.F.3 & $\begin{array}{c}1 \\
7 \\
14\end{array}$ & $\begin{array}{l}0.583^{\mathrm{NO}} \\
0.730^{\mathrm{KJ}} \\
0.816^{\mathrm{HG}}\end{array}$ & $\begin{array}{c}4.72^{\mathrm{D}} \\
4.62^{\mathrm{FG}} \\
4.51^{\mathrm{HKIJ}}\end{array}$ \\
\hline \multicolumn{2}{|r|}{ SED } & 0.008 & 0.012 \\
\hline \multicolumn{2}{|c|}{ R-Square } & 0.990 & 0.985 \\
\hline \multicolumn{2}{|c|}{ Coeff. Var. } & 1.884 & 0.467 \\
\hline
\end{tabular}

S.W. = Soft kishk like manufactured from fermented Whole Wheat Burghul Skim milk.

S.B. $=$ Soft kishk like manufactured from fermented Whole Barley Burghul Skim milk.

S.F. = Soft kishk like manufactured from fermented Freek Burghul Skim milk.

Starter $=1:(3 \%$ Yoghurt starter $), 2:(2 \%$ Yoghurt starter $+1 \%$ Bio- yoghurt starter $)$ and 3: ( $2 \%$ Yoghurt starter $+1 \%$ Lactobacillus plantarum $)$.

SED: Standard Error of Difference.

Table 3: Changes in $\mathrm{pH}$ values and acidity $\%$ of different cereal fermented dairy products during storage at $5 \pm 1^{\circ} \mathrm{C}$ for 14 days. fermented dairy products that fermented with only Yoghurt starter culture (1) were characterized with higher $\mathrm{pH}$ than that fermented with mixed cultures contain Yoghurt and Bio-Yoghurt starter (2) and mixed cultures of Yoghurt starter culture and Lactobacillus plantarum (3), respectively. During values of the storage at $5 \pm 1^{\circ} \mathrm{C}$ for 14 days, significant differences $(\mathrm{P} \leq 0.05)$ were recorded in $\mathrm{pH}$ of different cereal fermented dairy products. Moreover, a gradual decrease in $\mathrm{pH}$ could be observed in all samples of cereal fermented dairy products, with extending the cold storage period. The decrease in $\mathrm{pH}$ could be attributed to a limited growth of different bacterial starter cultures and the slow fermentation of residual lactose $[20,21]$.

The fermentation activity can be observed by acidity and/or $\mathrm{pH}$ measurements [22]. During fermentation of cereal fermented dairy products, the amount of organic acids other than lactic acid production were small and neglected in acidity calculations [23]. Unlike $\mathrm{pH}$, it is normal expected that the higher acidity rates would lead to lower $\mathrm{pH}$ values. The rates of acidity were higher in Barley samples than other samples of Wheat and Fereek [24-27]. The higher acidity of cereal fermented dairy products made with mix of Yoghurt starter culture and Lactobacillus plantarum culture can be attributed to the high activity of yogurt starter for splitting lactose into glucose and galactose as the first step of fermentation [28].

Table 4 illustrates the percentages of total solids, carbohydrates, ash, crude fiber, fat and crude protein of cereal fermented dairy products. There were no significant differences $(\mathrm{P}<0.05)$ in the crude protein for all samples, but significant $(\mathrm{P} \leq 0.05)$ in the carbohydrates, ash, crude fiber and fat contents between samples depending on type of cereals usage. The cereal fermented dairy products containing Freek were characterized with higher total solids and carbohydrates whereas, lower content of ash, crude fiber, fat and crude protein contents, compared with the other treatments. Also, depending on the type of starter culture, the cereal fermented dairy products fermented with only Yogurt starter showed very slight increase in the crude protein and carbohydrate contents, but decrease in moisture content than that fermented with mixed starter cultures except moisture content at (S. B. 1) treatment. As expected the crude fibers were higher in barley products than other samples because of its higher percent of crude fiber which reached $2.51 \%$. Also, it ranged from $0.702 \%$ to $0.709 \%$ in whole barley burghul fermented with reconstituted skim milk, but unlike contain whole wheat burghul and Freek products that ranged between

\begin{tabular}{|c|c|c|c|c|c|c|}
\hline Sample & Total Solids \% & Carbohydrates \% & Ash \% & Crude Fiber \% & Fat content $\%$ & Crude protein \% \\
\hline S.W.1 & $26.66^{A B}$ & $19.809^{A B}$ & $0.99^{A}$ & $0.388^{c}$ & $0.240^{A}$ & $5.243^{A}$ \\
\hline S.W.2 & $26.40^{\mathrm{BC}}$ & $19.687^{\mathrm{B}}$ & $0.96^{\mathrm{AB}}$ & $0.383^{c}$ & $0.234^{\mathrm{A}}$ & $5.143^{A}$ \\
\hline S.W.3 & $26.27^{\mathrm{C}}$ & $19.603^{\mathrm{B}}$ & $0.95^{\mathrm{B}}$ & $0.38^{\mathrm{c}}$ & $0.223^{\mathrm{B}}$ & $5.126^{A}$ \\
\hline S.B.1 & $25.76^{\mathrm{D}}$ & $18.930^{\mathrm{C}}$ & $0.88^{\mathrm{C}}$ & $0.708^{\mathrm{A}}$ & $0.198^{\mathrm{C}}$ & $5.18^{\mathrm{A}}$ \\
\hline S.B. 2 & $25.83^{\mathrm{D}}$ & $18.831^{c}$ & $0.87^{\mathrm{C}}$ & $0.705^{\mathrm{AB}}$ & $0.196^{c}$ & $5.13^{A}$ \\
\hline S.B.3 & $25.67^{\mathrm{E}}$ & $18.815^{\mathrm{C}}$ & $0.84^{\mathrm{C}}$ & $0.702^{\mathrm{B}}$ & $0.190^{\mathrm{CD}}$ & $5.11^{\mathrm{A}}$ \\
\hline S.F.1 & $26.69^{A}$ & $20.203^{A}$ & $0.76^{\mathrm{D}}$ & $0.285^{\mathrm{D}}$ & $0.183^{\mathrm{DE}}$ & $5.08^{A}$ \\
\hline S.F.2 & $26.37^{\mathrm{BC}}$ & $20.165^{A}$ & $0.74^{\mathrm{D}}$ & $0.283^{\mathrm{D}}$ & $0.183^{\mathrm{DE}}$ & $5.00^{A}$ \\
\hline S.F.3 & $26.38^{\mathrm{BC}}$ & $20.164^{A}$ & $0.75^{\mathrm{D}}$ & $0.282^{\mathrm{D}}$ & $0.180^{\mathrm{E}}$ & $5.00^{\mathrm{A}}$ \\
\hline SED & 0.053 & 0.088 & 0.007 & 0.001 & 0.001 & 0.057 \\
\hline R-Square & 0.955 & 0.950 & 0.985 & 0.999 & 0.980 & 0.517 \\
\hline Coeff. Var. & 0.353 & 0.783 & 1.50 & 0.441 & 1.502 & 1.940 \\
\hline
\end{tabular}

S.W. = Soft kishk like manufactured from fermented Whole Wheat Burghul Skim milk.

S.B. = Soft kishk like manufactured from fermented Whole Barley Burghul Skim milk.

S.F. $=$ Soft kishk like manufactured from fermented Freek Burghul Skim milk.

Starter $=1:(3 \%$ Yoghurt starter $), 2:(2 \%$ Yoghurt starter $+1 \%$ Bio-yoghurt starter $)$ and $3:(2 \%$ Yoghurt starter $+1 \%$ Lactobacillus plantarum $)$ SED: standard Error of Difference. 
$0.381-0.388$ and from $0.282 \%$ to $0.285 \%$, respectively. These differences of the chemical properties of cereal fermented dairy products, due to its chemical composition of cereal burghul and blends. It was reported that the type of starter culture used in the fermentation did not affect in the Total solids, fat and crude protein of yogurt, bio-yogurt [2029]. Also, Salama [30] noticed that the stirred fermented milk made by ABT-4 culture (Lb. acidophilus, Str. thermophilus and B. bifidum) observed slight decrease in crude protein than made by used YO-FLEX yogurt culture (Lb. delbruckii spp. lactis, Lb. delbruckii spp. bulgaricus and, Str. thermophilus); this may be due to the limited proteolysis of milk protein by lactic acid bacteria.

Suitability of heat treatments, good hygiene and microbiological analysis of characteristics of different blends

Table 5 illustrates the changes in the viable cell counts appeared on MRS medium for fresh and 14 days stored of cereal fermented dairy products at $5 \pm 1{ }^{\circ} \mathrm{C}$. Slight decrease were observed after 14 days of storage. Generally, the decreasing values were about 0.45 (c.f.u $\times 10^{3}$ $\mathrm{g}^{-1)}$. On the other hand, it can be noticed that the decline on MRS+LCysteine medium were less than that obtained in the case of MRS medium. The decreasing in values was $0.32,0.43$ and 0.44 (c.f.u $\times 10^{3} \mathrm{~g}^{-1)}$ for S.W. 2, S.B. 2 and S.F. 2 treatments, respectively. All the samples did not contain any growth in $0.1 \mathrm{gm}$ on SDA, VRBA, NA and MSA media in either fresh or stored products through the storage period. These results are revealed the good hygiene sanitation during manufacture different products. From the above results, it could be concluded that the c.f.u on MRS medium (mainly Bifidobacteria) sensitive than other starter microorganisms (mainly lactic acid bacteria) for storage.
Medina and Jordano [31] studied the survival of constitutive microflora in one batch of fermented milk containing Bifidobacteria during storage at $7^{\circ} \mathrm{C}$. Levels of Streptococcus thermophilus, Lactobacillus bulgaricus and Bifidobacterium spp. in initial population were 2.6 $\times 10^{8}, 5.1 \times 10^{7}$ and $7.4 \times 10^{6}$ c.f.u/ml respectively. Streptococcus thermophilus slightly increased after 10 days and then decreased. Numbers of Bifidobacterium and Lactobacillus bulgaricus decreased faster during storage. Also Shah et al. [32] studied the survival of Lactobacillus acidophilus and Bifidobacterium bifidum in commercial yoghurt during five weeks period under refrigerated storage. Viable cells of Lactobacillus acidophilus were $10^{7}$ to $10^{8} / \mathrm{g}$ in three of the five products, whereas the other two products contained less than $10^{5} / \mathrm{g}$. Initial count of Bifidobacterium bifidum was $10^{6}$ to $10^{7} / \mathrm{g}$ in two of five products, whereas the viable numbers were less than $10^{3} / \mathrm{g}$ in other three products. All the products showed a similar decline in the viable count of Lactobacillus acidophilus and Bifidobacterium bifidum during storage. Krasackoopt et al. [33] investigated the survival of the microcapsulated probiotics, Lactobacillus acidophilus 547, Bifidobacteria bifidum ATCC1994 and Lactobacillus casei 01 in stirred yoghurt from UHT and conventionally treated milk during low temperature storage at $4^{\circ} \mathrm{C}$ for 4 weeks. They found that the survival of encapsulated probiotic bacteria was higher than free cells bacteria were mentioned above. Also, they pointed that the viability of probiotic bacteria in yoghurt from both treatments was not significantly different.

The cereals can be used as fermentable substrates for the growth of probiotic microorganisms. Also, Lactobacillus acidophilus exhibited the poorest growth in malt, barley and wheat media, probably due to substrate deficiency in specific nutrients [25-34]. The optimum final

\begin{tabular}{|c|c|c|c|c|c|c|c|}
\hline \multirow{2}{*}{ Samples } & \multirow{2}{*}{$\begin{array}{c}\text { Storage Period } \\
\text { (Days) }\end{array}$} & \multicolumn{6}{|c|}{ Media } \\
\hline & & MRS & MRS+L- Cysteine & NA & SDA & VRBA & MSA \\
\hline S.W.1 & $\begin{array}{c}1 \\
7 \\
14\end{array}$ & $\begin{array}{l}2.80 \\
2.68 \\
2.40\end{array}$ & $\begin{array}{l}---- \\
---- \\
---\end{array}$ & & & & \\
\hline S.W.2 & $\begin{array}{c}1 \\
7 \\
14\end{array}$ & $\begin{array}{l}2.80 \\
2.72 \\
2.44\end{array}$ & $\begin{array}{l}2.56 \\
2.46 \\
2.24\end{array}$ & & & & \\
\hline S.W.3 & $\begin{array}{c}1 \\
7 \\
14\end{array}$ & $\begin{array}{l}2.84 \\
2.72 \\
2.44\end{array}$ & $\begin{array}{l}--- \\
--- \\
---\end{array}$ & & & & \\
\hline S.B.1 & $\begin{array}{c}1 \\
7 \\
14\end{array}$ & $\begin{array}{l}2.92 \\
2.72 \\
2.44\end{array}$ & $\begin{array}{l}--- \\
--- \\
---\end{array}$ & & & & \\
\hline S.B.2 & $\begin{array}{c}1 \\
7 \\
14\end{array}$ & $\begin{array}{l}2.88 \\
2.72 \\
2.48\end{array}$ & $\begin{array}{l}2.64 \\
2.44 \\
2.21\end{array}$ & & & & \\
\hline S.B.3 & $\begin{array}{c}1 \\
7 \\
14\end{array}$ & $\begin{array}{l}2.80 \\
2.68 \\
2.48\end{array}$ & ---- & & & & \\
\hline S.F.1 & $\begin{array}{c}1 \\
7 \\
14\end{array}$ & $\begin{array}{l}2.72 \\
2.52 \\
2.28\end{array}$ & --- & & & & \\
\hline S.F.2 & $\begin{array}{c}1 \\
7 \\
14\end{array}$ & $\begin{array}{l}2.84 \\
2.68 \\
2.48\end{array}$ & $\begin{array}{l}2.56 \\
2.42 \\
2.12\end{array}$ & & & & \\
\hline S.F.3 & $\begin{array}{c}1 \\
7 \\
14\end{array}$ & $\begin{array}{l}2.76 \\
2.64 \\
2.40\end{array}$ & $\begin{array}{l}---- \\
---- \\
---\end{array}$ & & & & \\
\hline
\end{tabular}

S.W. = Soft kishk like manufactured from fermented Whole Wheat Burghul Skim milk.

S.B. = Soft kishk like manufactured from fermented Whole Barley Burghul Skim milk.

S.F. = Soft kishk like manufactured from fermented Freek Burghul Skim milk.

Starter: 1: (3\% Yoghurt starter), 2: (2\% Yoghurt starter $+1 \%$ Bio-yoghurt starter) and 3: ( $2 \%$ Yoghurt starter $+1 \%$ Lactobacillus plantarum)

ND: Not Detected in 0.1 gm; (--): Not determined; VRBA: Violet Red Bile Agar; NA: Nutrient Agar; MSA: Manitol Salt Agar; SDA: Sabouraud Dextrose Agar; MRS: Man Rogosa Sharpe Agar

Table 5: Changes in viable microbial counts (c.f.u $\times 10^{-3} / \mathrm{g}$ ) in cereal fermented dairy products during storage at $5 \pm 1^{\circ} \mathrm{C}$. 


\begin{tabular}{|c|c|c|c|c|c|}
\hline Sample & Storage Period (days) & Flavor (10) & Body/texture (5) & Appearance and color (5) & Total (20) \\
\hline S.W.1 & $\begin{array}{c}1 \\
7 \\
14\end{array}$ & $\begin{array}{c}7.83^{\mathrm{AB}} \\
7.66^{\mathrm{AB}} \\
6.00^{\mathrm{BCDEF}}\end{array}$ & $\begin{array}{l}4.00^{\mathrm{A}} \\
3.83^{\mathrm{A}} \\
3.66^{\mathrm{A}}\end{array}$ & $\begin{array}{r}4.33^{\mathrm{A}} \\
3.83^{\mathrm{ABC}} \\
3.66^{\mathrm{ABC}}\end{array}$ & $\begin{array}{c}16.16^{\mathrm{A}} \\
15.32^{\mathrm{AB}} \\
13.32^{\mathrm{ABCD}}\end{array}$ \\
\hline S.W.2 & $\begin{array}{c}1 \\
7 \\
14\end{array}$ & $\begin{array}{c}7.66^{\mathrm{AB}} \\
7.00^{\mathrm{ABCD}} \\
6.16^{\mathrm{ABCDEF}}\end{array}$ & $\begin{array}{l}4.50^{\mathrm{A}} \\
4.00^{\mathrm{A}} \\
3.83^{\mathrm{A}}\end{array}$ & $\begin{array}{l}4.33^{\mathrm{A}} \\
4.00^{\mathrm{AB}} \\
3.5^{\mathrm{ABC}}\end{array}$ & $\begin{array}{c}16.49^{\mathrm{A}} \\
15^{\mathrm{AB}} \\
13.49^{\mathrm{ABCD}}\end{array}$ \\
\hline S.W.3 & $\begin{array}{c}1 \\
7 \\
14\end{array}$ & $\begin{array}{l}7.33 \mathrm{~A}^{\mathrm{BC}} \\
7.00^{\mathrm{ABCD}} \\
5.83^{\mathrm{BCDEF}}\end{array}$ & $\begin{array}{l}4.33^{\mathrm{A}} \\
3.83^{\mathrm{A}} \\
3.66^{\mathrm{A}}\end{array}$ & $\begin{array}{c}4.33^{\mathrm{A}} \\
4.16^{\mathrm{AB}} \\
3.83^{\mathrm{ABC}}\end{array}$ & $\begin{array}{c}15.99^{\mathrm{AB}} \\
14.99^{\mathrm{AB}} \\
13.32^{\mathrm{ABCD}}\end{array}$ \\
\hline S.B.1 & $\begin{array}{c}1 \\
7 \\
14\end{array}$ & $\begin{array}{c}6.00^{\mathrm{BCDEF}} \\
5.00^{\mathrm{DEF}} \\
4.33^{\mathrm{EF}}\end{array}$ & $\begin{array}{l}3.66^{A} \\
3.66^{A} \\
3.00^{A}\end{array}$ & $\begin{array}{c}3.5^{\mathrm{A}} \\
2.5^{\mathrm{ABC}} \\
2.33^{\mathrm{BC}}\end{array}$ & $\begin{array}{c}13.16^{\mathrm{ABCD}} \\
11.16^{\mathrm{BCD}} \\
9.66^{\mathrm{CD}}\end{array}$ \\
\hline S.B.2 & $\begin{array}{c}1 \\
7 \\
14\end{array}$ & $\begin{array}{l}5.66^{\mathrm{BCDEF}} \\
5.00^{\mathrm{DEF}} \\
4.00^{\mathrm{F}}\end{array}$ & $\begin{array}{l}3.66^{A} \\
3.66^{A} \\
2.66^{A}\end{array}$ & $\begin{array}{c}3.16^{\mathrm{ABC}} \\
2.5^{\mathrm{ABC}} \\
2.33^{\mathrm{BC}}\end{array}$ & $\begin{array}{c}12.48^{\mathrm{ABCD}} \\
11.16^{\mathrm{BCD}} \\
9.33^{\mathrm{CD}}\end{array}$ \\
\hline S.B.3 & $\begin{array}{c}1 \\
7 \\
14\end{array}$ & $\begin{array}{c}6.33^{\mathrm{ABCDE}} \\
5.00^{\mathrm{DEF}} \\
4.00^{\mathrm{F}}\end{array}$ & $\begin{array}{l}4.00^{A} \\
3.66^{A} \\
3.00^{A} \\
\end{array}$ & $\begin{array}{l}3.5^{\mathrm{ABC}} \\
2.5^{\mathrm{ABC}} \\
2.00^{\mathrm{C}}\end{array}$ & $\begin{array}{c}13.83^{\mathrm{ABCD}} \\
11.16^{\mathrm{BCD}} \\
9.00^{\mathrm{D}}\end{array}$ \\
\hline S.F.1 & $\begin{array}{c}1 \\
7 \\
14\end{array}$ & $\begin{array}{c}8.33^{\mathrm{A}} \\
6.33^{\mathrm{ABCDE}} \\
5.66^{\mathrm{BCDEF}}\end{array}$ & $\begin{array}{l}4.00 \mathrm{~A} \\
4.00 \mathrm{~A} \\
3.83 \mathrm{~A}\end{array}$ & $\begin{array}{l}4.33^{\mathrm{A}} \\
4.33^{\mathrm{A}} \\
3.5^{\mathrm{ABC}}\end{array}$ & $\begin{array}{c}16.66^{\mathrm{A}} \\
14.66^{\mathrm{AB}} \\
12.99^{\mathrm{ABCD}}\end{array}$ \\
\hline S.F.2 & $\begin{array}{c}1 \\
7 \\
14\end{array}$ & $\begin{array}{c}7.83^{\mathrm{AB}} \\
6.33^{\mathrm{ABCDE}} \\
5.16^{\mathrm{CDEF}}\end{array}$ & $\begin{array}{l}4.00^{A} \\
3.66^{A} \\
3.00^{A}\end{array}$ & $\begin{array}{c}4.33^{A} \\
4.00^{A B} \\
3.66^{A B C}\end{array}$ & $\begin{array}{c}16.16 \mathrm{~A} \\
13.99^{\mathrm{ABC}} \\
11.82^{\mathrm{ABCD}}\end{array}$ \\
\hline S.F.3 & $\begin{array}{c}1 \\
7 \\
14\end{array}$ & $\begin{array}{c}7.83^{\mathrm{AB}} \\
7.00^{\mathrm{ABCD}} \\
6.00^{\mathrm{BCDEF}}\end{array}$ & $\begin{array}{l}4.00^{\mathrm{A}} \\
4.00^{\mathrm{A}} \\
3.33^{\mathrm{A}}\end{array}$ & $\begin{array}{c}4.33^{\mathrm{A}} \\
3.66^{\mathrm{ABC}} \\
3.5^{\mathrm{ABC}}\end{array}$ & $\begin{array}{c}16.16^{A} \\
14.66^{A B C D} \\
12.83 A^{B C D}\end{array}$ \\
\hline \multicolumn{2}{|c|}{ SED } & 0.420 & 0.340 & 0.343 & 0.883 \\
\hline \multicolumn{2}{|c|}{ R-Square } & 0.805 & 0.383 & 0.679 & 0.754 \\
\hline \multicolumn{2}{|c|}{ Coeff. Var. } & 11.686 & 15.81 & 16.93 & 11.34 \\
\hline
\end{tabular}

S.W. $=$ Soft kishk like manufactured from fermented Whole Wheat Burghul Skim milk.

S.B. = Soft kishk like manufactured from fermented Whole Barley Burghul Skim milk.

S.F. = Soft kishk like manufactured from fermented Freek Burghul Skim milk.

Starter $=1:(3 \%$ Yoghurt starter $), 2:(2 \%$ Yoghurt starter $+1 \%$ Bio-yoghurt starter $)$ and $3:(2 \%$ Yoghurt starter $+1 \%$ Lactobacillus plantarum $)$.

SED: Standard Error of Difference.

Table 6: Organoleptic properties of cereal-based fermented dairy products, during storage at $5 \pm 1{ }^{\circ} \mathrm{C}$ for 14 days.

$\mathrm{pH}$ and the concentration of lactic and acetic acid in fermented cereal product in relation to the properties of each specific probiotics strain have to be investigated in order to maximise the viability during storage for practical application; a $\mathrm{pH}$ value of the final product must be maintained above 4.6 to prevent the decline Bifidobacteria population [35].

\section{The sensory evaluation}

The sensory evaluation is the main factor affecting the consumption of the products and its acceptance. It was realized that the sensory evaluation could contribute pertinent, valuable information related to marketing consequences and simultaneously provide direct actionable information [15]. The scores for organoleptic properties of cereal fermented dairy products prepared using whole wheat burghul or whole barley burghul or freek burghul with different types of starter cultures, during storage at $5 \pm 1^{\circ} \mathrm{C}$ for 14 days were presented in Table 6 and Figure 2. It was clear that in fresh products (first day of storage), the addition of wheat or Freek burghul didn't affect the general acceptability of them, whereas the addition of barley burghul had lowering the total score. General acceptability of the cereal fermented dairy products containing Freek; especially when fermented with yogurt culture (S.F.1) treatment; was gained the highest scores in the organoleptic properties followed by their containing of wheat (S.W.2) product. The cereal fermented dairy products containing of Freek were characterized with perfect flavor, body and texture as well as whiteness appearance and colour. On the other hand, the pronounced malt flavor and light brown color or the decline of color to un-natural, were noticed in cereal fermented dairy products containing of barely; especially at (S.B.2) treatment, these results are in agreement with [20]. During storage at $5 \pm 1^{\circ} \mathrm{C}$ for 14 days, Sensory evaluation was decreased for all products due to the acidity increased in all samples gradually and effect on organoleptic properties and decreased its total score. Vijayalakshmi et al. [36] found that during storage of cereal based low fat fruit yogurt, acidic or malt flavor, firm or ropy body and texture, shrunken or free whey appearance, as well as light brown color were increased in different cereal fermented dairy products at the end of storage.

At the end of storage time, whole wheat burghul treatments had the highest total scores and then, the Freek burghul samples, while the addition of Whole barley burghul had the lowest total score because of high viscosity and unnatural color and still not acceptable at the end of storage. Blanddino et al. [8] mentioned that during cereal fermentations several volatile compounds are formed, which contribute to a complex blend of flavors in the products [37]. Moreover, the presence of aromas representative of Diacetyl acetic acid and butyric acid make fermented cereal-based products more appetizing. Also, Salmeron et al. [38] found that incubation with the probiotic LAB caused a significant change in the aroma profile of the four cereal broths. In barely, considerable amounts of new volatiles were generated after the fermentation. In general, the volatile production depends more on the substrate than on the microorganisms.

\section{Conclusion}

From the above results it could be concluded that either Whole 
Citation: Nassar KS, Shamsia SM, Attia IA (2016) Improvement of the Nutritional Value of Cereal Fermented Milk: 1- Soft Kishk Like. J Food Process Technol 7: 619. doi: 10.4172/2157-7110.1000619

Page 7 of 7

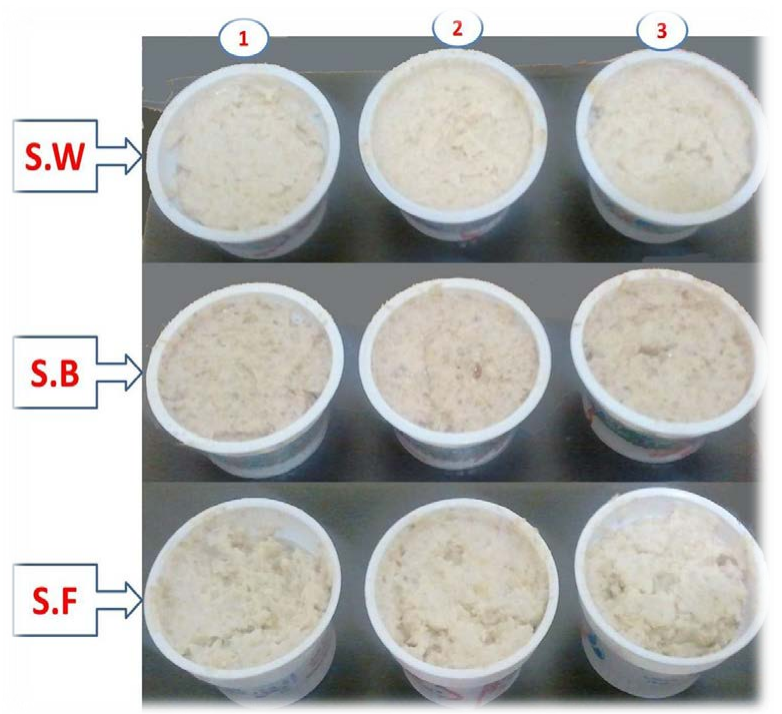

S.W. = Soft kishk like manufactured from fermented Whole Wheat Burghul Skim milk.

S.B. = Soft kishk like manufactured from fermented Whole Barley Burghul Skim milk.

S.F. = Soft kishk like manufactured from fermented Freek Burghul Skim milk Starter $=1:(3 \%$ Yoghurt starter $), 2:(2 \%$ Yoghurt starter $+1 \%$ Bio-yoghurt starter) and 3: ( $2 \%$ Yoghurt starter $+1 \%$ Lactobacillus plantarum).

Figure 2: The pictures of soft Kishk like products.

Wheat Burghul, Whole Barley Burghul and Whole Freek Burghul can be used to produce an acceptable product as functional foods suitable for elderly persons or infants weaning foods. This formula has a high nutritional value and fiber content beside the presence probiotic bacteria with a lot of health benefits.

\section{References}

1. Metchnikoff E (1907) Essays optimists Paris: The prolongation of life. Optimistic studies. Translated and edited by P Chalmers Mitchell. London Heinemann.

2. Fuller R (1989) Probiotics in man and animals. J Appl Bacterial 66: 365-378.

3. Fuller R (1991) Probiotics in human medicine. Gut 32: 439-442.

4. Jones PJ (2002) Clinical nutrition 7: Functional foods- More than just nutrition. Canadian Med Assoc J (CMAJ) 166: 1555-1563.

5. Charalampopoulos D, Wang R, Pandiella SS, Webba C ( 2002b) Application of cereals and cereal components in functional foods: a review. Int $\mathrm{J}$ food Microbiol 79: 134.

6. Hambraeus L (1992) Nutritional aspects of milk proteins. In Fox PF (Ed) Advanced dairy chemistry 1: proteins. Elsevier Applied Science. London: 457-490.

7. Gomez-Ruiz JA, Ramos, Reciol I (2002) Angiotensin converting enzyme inhibitory peptides in Manchego cheeses manufactured with different starter cultures. Int Dairy J 12: 697-706.

8. Blandino A, AL-Aseeria ME, Pandiella SS, Canterob D, Webba C, et al. (2003) Review cereal-based fermented foods and beverages. Food Res Int 36: 527.

9. Lorri W, Svanberg U (1993) Lactic fermented cereal gruels with improved in vitro protein digestibility. Int J Food Sci Nutr 44: 29.

10. Sanni Al, Ohilude AA, Ibidabpo OT (1999) Biochemical composition of infant weaning food fabricated from fermented blends of cereals and soybean. Food Chem 65: 35.

11. Damiani P, Gobbetti M, Cossignani L, Corsetti A, Simonetti MS, et al. (1996) The sourdough microflora. Characterisation of hetero and homofermentative lactic acid bacteria, yeasts and their interaction on the basis of the volatile compounds produced. LWT Food Sci. and Technol 29: 63.

12. AOAC (2007) Official methods of analysis (18thedn). Association of Official Agricultural Chemists, $\mathrm{CH}$, Washington D.C., USA 34: 72-80.
13. AACC (2003) Approved methods of the American Association of Cerea Chemists (8thedn.). AACC, St Paul, USA.

14. Richardson HG (1986) Standard methods for the examination of dairy products (15thedn.). American Public Health Association Inc, Washington, USA.

15. Clark S, Costello M, Drake M, Body-felt F (2009) The Sensory evaluation of dairy products. Springer.

16. APHA (1992) American Public Health Association standard method for the examination of dairy products (16thedn.). Washington DC, USA.

17. Difco (1984) Manual of dehydrated culture media and reagent for microbiological and clinical laboratories. Detroit, Michigan, USA.

18. Lapierra LP, Undeland P, Cox LJ (1992) Lithium chloride-Sodium propionate agar for the enumeration of Bifidobacteria in fermented dairy products. J Dairy Sci 75: 1192.

19. SAS (2013) Statistical Analysis System User Guide Version 9.3. SAS Institute Inc. Cary, NC, USA.

20. Hussein GAM (2011) Production and properties of some cereal-based functional fermented dairy products. Egyptian J Dairy Sci 39: 89-100.

21. Barrantes E, Tammime AY, Muir DD, Swoed AM (1994) The effect of substitution of fat by micro-particulated whey protein on the quality of set-type natura yoghurt. J Soci Dairy Technol 47: 61.

22. Hesseltine CW (1979) Some important fermented foods of Mid-Asia the Middle East and Africa. J of American Oil Chemists' Soci 56: 367-374.

23. Damir AA, Salama AA, Mohamed MS (1992) Acidity microbial organic and free amino acid development during fermentation of skimmed milk, kishk. Food Chemi. 43: 265-269.

24. Mehanna AS, Hefnawy SA (1990) A Study to follow the chemical changes during processing and storage of zabady. Egypt J Dairy Sci 18: 425-434.

25. Mehanna AS (1991) An attempt to improve some properties of zabadi by applying low temperature long incubation period in the manufacturing process. Egypt Dairy Sci 19: 221-229.

26. Abou-Donia SA, Attia IA, Khattab AA, El-Shenawy Z (1991) Studies on the formation of fermented milk for infantile and geriatric nutrition. Egypt J Dairy Sci 19: 283-299.

27. Kailasapathy K, Rybka S (1997) Lactobacillus acidophilus and Bifidobacterium spp. their therapeutic potential and survival in yoghurt. Australian J Dairy Tech 52: 28

28. Tamine Ay, Rbinson Rk (1985) Yoghurt Science and technology pergamon press. Publisgar Robert Maxuell MG London.

29. Aklain AS (1996) L (+) D (-) Lactic acid content and aroma profile in bioghurt bifigurt biograde in comparison with yougurt. Egypt J Dairy Sci 24: 227.30.

30. Salama FM (2002) Production of therapeutic and diabetic stirred yoghurt-like fermented milk products. Egypti. J Dairy Sci 30: 177

31. Medina LM, Jordano R (1994) Survival of constitute microflora in commercially fermented milk containing Bifidobacteria during refrigerated storage. J Food Prot 58: 70-75 Cited from Int Dairy J 7: 349-356.

32. Shah NP, Lankaputhra WEV, Britz ML, kyle WSA (1995) Survival of lactobacillus and Bifidobacterium bifidum in commercial yoghurt during refrigerated storage. Int. Dairy J 5: 515-521.

33. Krasackoopt W, Bhandari B, Deeth HC (2004) Survival of probiotic encapsulated in chitsason-coated alginate beads in yoghurt from UHT. And conventionally treated milk during storage. LWT Food Sci Technol 39: 177-183.

34. Charalampopoulos D, Pandiella SS, Webba C (2002a) Growth studies of potentially probiotic lactic acid bacteria in cereal based substrates. J Appl Microbiol 92: 851.

35. Vinderola CG, Bailo N, Reinheimer JA (2000) Survival of probiotic microflora in Argentinian yougurts during refrigerated storage. Food Res Int 33: 97.

36. Vijayalakmi R, Nareshkumar C, Dhanalashmi B (2010) Storage studies of cereal based low fat fruit yoghurt. Egypti J Dairy Sci 38: 53-61.

37. Chavan Jk, Kadam SS (1989) Nutritional improvement of cereals by fermentation. Crit Rev Food Sci Nutr 28: 349.

38. Salmeron I, Charalampopoulos D, Pandiella SS (2009) Volatile compounds produced by the probiotic strain Lactobacillus Plantarum NCIMB 8826 in cereal-based substrates. Food chem 117: 265 